\title{
KONSEP PEMIKIRAN HARUN AR-RASYID DALAM PENDIDIKAN KARAKTER
}

\author{
Ahmad Afnan Anshori \\ Universitas Islam Negeri Walisongo Semarang, Indonesia \\ Afnan_ahmad@yahoo.com
}

\begin{abstract}
CHARACTER BUILDING IN HARUN AR-RASYID THOUGH. ampant cases of violence in society, political instability, as well as the moral degradation of the nation as a whole raises awareness of the importance of good character development at the level of the family as an institution forming the smallest nation to the character development of the nation at large. In addition to the family, the environment and education institutions also bave a role no less important in the formation of national character, it's because the institution is spearheading the development of the nation in the realm of formal education. Education as a process that helps mature, directing and developing the potential in man is regarded as an appropriate means in the formation of one's character. One of the concepts of character education is found in the will written by Harun ar-Rashid to al-Ahmar the teacher who is appointed by the Caliph to educate the crown prince, later known as al-Amin. In this testament, there are several character education concepts, including role models of teachers, obedience, respect for family, teaching the Qur'an and Sunnah as well as many others. The concept of character education promoted by Harun ar-Rashid was not different from the concept of character education offered by modern education experts, this proves that the concept of character education contained in the will of Harun al-Rashid is universal without any limitation of space and time.
\end{abstract}

Keywords: Character Education, Harun Ar-Rashid, Al-Ahmar, Al-Amin 


\begin{abstract}
Abstrak
Maraknya kasus-kasus kekerasan di tengah masyarakat, instabilitas politik, serta degradasi moral bangsa secara keseluruban memunculkean kesadaran akan pentingnya pembangunan karakter baik pada tingkat keluarga sebagai institusi terkecil pembentuk bangsa bingga pada pembangunan karakter bangsa secara luas. Selain keluarga, lingkungan dan juga lembaga pendidikan mempunyai peran yang tidak kalah penting dalam proses pembentukan karakter bangsa, hal ini karena lembaga pendidikan adalah ujung tombak pembangunan bangsa dalam ranah edukasi formal. Pendidikan sebagai proses yang membantu mendewasakan, mengarabkan dan mengembangkan potensi dalam diri manusia dianggap sebagai sarana yang tepat dalam pembentukan karakter seseorang. Salab satu konsep pendidikan karakter ditemukan dalam wasiat yang ditulis oleh Harun ar-Rasyid kepada al-Ahmar seorang guru yang ditunjuk oleh sang khalifah untuk mendidik putra mahkotanya yang kemudian dikenal dengan al-Amin. Dalam wasiat ini terdapat beberapa konsep pendidikan karakter, diantaranya ketauladanan seorang guru, ketaatan, penghormatan pada keluarga, pengajaran al quran dan Sunnah serta banyak lagi yang lainnya. Konsep pendidikan karakter yang diususng oleb Harun ar-Rasyid tidak berbeda dengan konsep pendidikan karakter yang ditawarkan oleh para pekar pendidikan modern, hal ini membuktikan babwa konsep pendidikan karakter yang terdapat dalam wasiat Harun ar-Rasyid ini bersifat universal tanpa batasan ruang dan wak.tu.
\end{abstract}

Kata Kunci: Pendidikan Karakter, Harun Ar-Rasyid, Al-Ahmar, Al-Amin

\title{
A. Pendahuluan
}

Pendidikan merupakan pintu menuju kemajuan dan peningkatan kualitas kehidupan manusia. Pendidikan ideal yang merupakan proses pembentukan kepribadian telah dicontohkan oleh Rasulullah saw. Sejarah telah menunjukkan kepada kita bagaimana keberhasilan Rasulullah saw mendidik para sahabat beliau menjadi pribadi yang memiliki akhlak sempuna, jiwa yang bersih serta mempunyai keseimbangan pola pikir dan prilaku hingga mampu mencapai kebahagiaan duniawi bahkan telah 
dijamin oleh Allah sebagai tamu yang akan menghuni surgaNya kelak.

Tentu saja keberhasilan ini membutuhkan proses yang tidak sebentar serta menuntut pengorbanan yang tidak sedikit. Satu hal yang menjadi kunci keberhasilan pendidikan yang telah diterapkan oleh Rasulullah saw adalah bahwa Rasulullah saw sebagai seorang guru mampu menjadi tauladan yang sempurna bagi para sahabat yang merupakan murid-murid beliau. Bahkan dalam sebuah hadits sahih disebutkan bahwa Rasulullah saw menunjuk generasi para sahabat adalah generasi terbaik umat ini, lalu disusul generasi para tabi'in dan seterusnya. Dari Imran bin Hushain RA, bahwa dia mendengar Rasulullah saw bersabda:

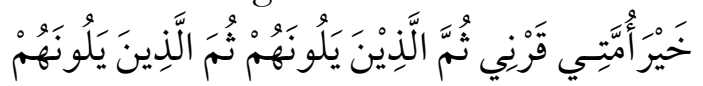

"Sebaik-baik umatku adalah pada masaku. Kemudian orang-orang yang setelah mereka (generasi berikutnya), lalu orang-orang yang setelah mereka." (Shahih Al-Bukhari, no. 3650)

Sungguh merupakan anugerah yang tidak ternilai menjadi ummat Rasulullah saw. Meski kita tidak termasuk dalam tiga generasi yang telah diakui Rasulullah saw sebagai generasi terbaik, tapi kita telah diberi warisan yang sangat berharga terkait dengan metode dan konsep pendidikan beliau. Sehingga merupakan satu keharusan bagi kita untuk terus menjadikan metode pendidikan yang telah diwariskan itu tidak hanya sebagai khazanah keilmuan yang kita bangga-banggakan, namun juga menjadikannya sebagai metode pendidikan di era modern ini, agar kita mampu menjadikan generasi ummat ini sebagai generasi yang unggul tidak hanya dalam intelektualitas namun juga dalam moralitas.

Di era modern ini telah banyak ditemukan berbagai metode pendidikan, baik yang diusung oleh para tokoh pendidikan barat maupun tokoh pendidikan dari dunia Islam sendiri. Dari sekian banyak metode pendidikan yang telah dirumuskan oleh para pakar pendidikan itu, sebenarnya kata kunci keberhasilannya kembali pada kemampuan para pendidik untuk menjadi contoh 
nyata atau tauladan bagi para peserta didiknya, sebagaimana yang telah dilakukan oleh Rasulullah saw. Tanpa kemampuan untuk menjadi tauladan ini, maka bisa dikatakan mustahil suatu proses pendidikan bisa berhasil. Falsafah ketauladanan ini sebenarnya juga diamini oleh para pendahulu kita di Indonesia. Lihatlah sebutan yang diberikan kepada para pendidik "guru" yang merupakan kependekan dari sosok yang bisa digugu dan ditiru.

Salah satu pondasi penting dan mendapat perhatian serius dalam pendidikan adalah pembentukan karakter atau akhlak. Indonesia sebagai Negara yang juga memberi perhatian terhadap keberlangsungan pendidikan juga ikut menggaungkan pendidikan karakter. Kabar gembira bagi para pemerhati pendidikan moral di tanah air terwujud dalam kebijakan yang dituangkan dalam UU sisdiknas 2003. Dalam pasal 1 UU sisdiknas 2003 ini disebutkan bahwa salah satu tujuan pendidikan nasional adalah mengembangkan potensi peserta didik agar memiliki kecerdasan, kepribadian dan akhlak mulia. Bahkan secara lebih tegas disebutkan bahwa tujuan asasi dari pembangunan nasional 20102014 adalah pembentukan akhlak mulia dan karakter bangsa.

Maraknya kasus-kasus kekerasan di tengah masyarakat, instabilitas politik, serta degradasi moral bangsa secara keseluruhan memunculkan kesadaran akan pentingnya pembangunan karakter baik pada tingkat keluarga sebagai institusi terkecil pembentuk bangsa hingga pada pembangunan karakter bangsa secara luas. Selain keluarga, lingkungan dan juga lembaga pendidikan mempunyai peran yang tidak kalah penting dalam proses pembentukan krakter bangsa, hal ini karena lembaga pendidikan adalah ujung tombak pembangunan bangsa dalam ranah edukasi formal. Pendidikan sebagai proses yang membantu mendewasakan, mengarahkan dan mengembangkan potensi dalam diri manusia dianggap sebagai sarana yang tepat dalam pembentukan karakter seseorang. ${ }^{1}$

${ }^{1}$ D. Yahya, Khan, Pendidikan Karakter Berbasis Potensi Diri. (Yogyakarta: Pelangi Publishing. 2010), hlm. 1. 
Apa sebenarnya yang dimaksud dengan karakter dalam terma pendidikan ini? Sudah banyak definisi yang dituangkan oleh para pakar tentang definisi karakter dan pendidikan karakter. Dalam Kamus Besar Bahasa Indonesia disebutkan bahwa karakter adalah tabiat, sifat-sifat kejiwaan, akhlak atau budi pekerti yang membedakan seseorang dengan yang lain, dan watak. Sementara itu Yahya Khan menyatakan bahwa karakter adalah sikap pribadi yang stabil sebagai hasil proses konsolidasi secara progresif dan dinamis, serta merupakan integrasi pernyataan dan perbuatan ${ }^{2}$.

Menurut Thomas Lickona, karakter adalah "A reliable disposition to respond to situations in a morally good way." Selanjutnya ia menambahkan bahwa "character so conceived has three interrelated parts: moral knowing, moral feeling, and moral behavior". ${ }^{3}$ Disini, lickona menyatakan bahwa karakter itu terbentuk melalui tiga pilar utama, yaitu pengetahuan atau motivasi, perasaan dan perilaku.

Menurut Hamid dan Saebani ada sembilan pilar karakter yang terpancar dari nilai-nilai luhur universal. Pertama, karakter cinta Tuhan dan segenap ciptaan-Nya; kedua, kemandirian dan tanggung jawab; ketiga, kejujuran atau amanah; keempat, hormat dan santun; kelima, dermawan, suka menolong dan gotong royong; keenam, percaya diri dan pekerja keras; ketujuh, kepemimpinan dan keadilan; kedelapan, baik dan rendah hati; kesembilan, karakter toleransi, kedamaian dan kesatuan.

Dalam konteks pembangunan bangsa, pendidikan karakter merupakan usaha sadar dan terencana untuk mewujudkan suasana serta proses pemberdayaan potensi dan pembudayaan peserta didik guna membangun karakter pribadi atau kelompok yang diharapkan mampu memberikan kontribusi optimal dalam rangka mewujudkan masyarakat sebagaimana dimanatkan oleh Pancasila. ${ }^{4}$

\footnotetext{
${ }^{2}$ Ibid., hlm. 1.

${ }^{3}$ Hamdani Hamid dan Beni Ahmad Saebani Pendidikan Karakter Perspektif Islam. (Bandung: Pustaka Setia. 2013), hlm. 31.

${ }^{4}$ Ibid., hlm. 39.
} 
Dalam Islam, sebenarnya pendidikan karakter bukanlah merupakan satu hal yang baru. Bahkan pendidikan karakter yang dalam Islam disebut sebagai akhlak merupakan misi utama dari pengangkatan Muhammad sebagai utusan Allah swt sebagaimana tercermin dalam sabda Rasulullah saw yang berbunyi:

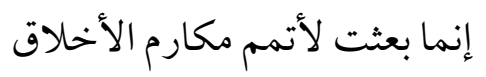

Menjadikan pendidikan akhlak sebagai tujuan utama kerasulan tentu merupakan satu sinyal yang disampaikan oleh Allah agar manusia benar-benar serius memperhatikan dan menjaga kualitas akhlak mereka, tidak hanya akhlak yang terkait dengan hubungan vertikal manusia dengan Tuhannya namun juga hubungan horizontal antar sesama manusia. Bahkan Islam merupakan satu-satunya agama di bumi ini yang secara detail memberikan panduan lengkap terkait dengan tata-cara teknis perilaku kehidupan manusia. Lihat saja bagaimana Islam menjelaskan secara rinci adab atau sopan-santun dan tata-cara bersuci, bertamu, berbicara, menyampaikan pendapat, bahkan tata-cara makan sekalipun. Sungguh ajaran yang luar biasa lengkap dan menyeluruh.

Sedemikian besar perhatian Islam terhadap pendidikan akhlak, hingga sangat disayangkan jika lembaga pendidikan berlabel Islam tidak mampu menjaga amanah yang telah disampaikan oleh Rasulullah terkait pendidikan akhlak, karena pada hakekatnya umat Islam secara keseluruhan merupakan penerus perjuangan yang telah dirintis oleh Rasulullah saw.

Sebagaimana telah dipaparkan, bahwa pendidikan karakter harus melibatkan tiga unsur utama: kognitif, afektif dan psikomotorik. Ketiga unsur ini dalam Islam disebut sebagai aqidah, ibadah dan muamalah, atau disebut juga sebagai Islam, Iman dan Ihsan. Tentu saja ketiga unsur ini harus saling mendukung dan melengkapi agar karakter atau akhlak yang terbentuk benar-benar terbangun atas landasan Islam, Iman dan Ihsan. Konsep Islam merupakan representasi dari ilmu atau ranah 
kognitif tentang segala sesuatu yang harus dilakukan dan harus ditinggalkan oleh seorang muslim, konsep Iman merupakan representasi dari ranah psikomotorik dimana ilmu yang telah diketahui dan diyakini harus diaplikasikan dalam kehidupan nyata, baik secara lisan maupun perbuatan, sementara Ihsan merupakan representasi dari ranah afektif, dimana prilaku seseorang haruslah bisa dipertanggungjawabkan secara moral berdasarkan nilai-nilai universal.

\section{B. Pembahasan.}

\section{Biografi Harun ar-Rasyid}

Harun ibn Muhammad ibnu Abi Ja'far al-Manshur adalah khalifah kelima dalam dinasti Abbasiyah. Beliau merupakan putra termuda dari Muhammad ibnu Ja'far Al-Manshur yang kemudian dikenal dengan khalifah al-Mahdi. Harun lahir dari seorang ibu berdarah Iran bernama Khaizran yang pada mulanya merupakan seorang budak. Dengan demikian, dalam diri Harun mengalir darah Arab dan Iran sekaligus. ${ }^{5}$

Harun ibn Muhammad menduduki kursi kekhalifahan pada tahun $170 \mathrm{H} / 786 \mathrm{M}$ menggantikan saudaranya khalifah alHadi dengan gelar kehormatan Harun ar-Rasyid. Pada saat itu Harun ibn Muhammad baru berusia 25 tahun. ${ }^{6}$ Usia yang masih sangat muda untuk menduduki puncak kekuasan sebuah dinasti dengan wilayah kekuasaan yang luas. Namun usia yang masih muda ini justru merupakan salah satu faktor yang mendukung keberhasilan Harun ar-Rasyid membawa dinasti Abbasiyyah di bawah kepemimpinannya mencapai masa keemasan.

Pada masa itu, Harun Ar-rasyid merupakan sosok yang sangat disegani dan dihormati, tidak hanya oleh para penduduk

${ }^{5}$ Joesoef Sou'yb, Sejarah Daulat Abbasiyah I (Jakarta: Penerbit Bulan Bintang. 1997), hlm. 38.

${ }^{6}$ Ibid., hlm. 102.

${ }^{7}$ Fatah Syukur NC, SejarabPeradaban Islam. (Semarang: Pustaka Rizki Putra, 2009), hlm. 99. 
negeri Abbasiyyah namun juga oleh para pemuka negara-negara tetangga. ${ }^{8}$ Sebagai seorang khalifah, Harun ar-rasyid dikenal sebagai sosok yang alim dan juga tidak segan untuk turun sendiri ke medan perang memimpin pasukannya. Setiap tahun secara berselang-seling Harun ar-Rasyid selalu melaksanakan ibadah haji atau berperang. Kemewahan yang melingkarinya tidak lantas menjadikannya sombong. Harun ar-Rasyid selalu melaksanakan ibadah haji berjalan kaki, setiap harinyapun tak kurang dari seratus rakaat shalat didirikannya. ${ }^{9}$

Harun ar-Rasyid dikenal sebagai pemimpin yang adil dan memperhatikan kesejahteraan rakyatnya. Pada masa kepemimpinan Harun ar-Rasyid, baitul mal bertugas untuk mencukupi kebutuhan pokok para penduduk, termasuk untuk mencukupi kebutuhan makan dan minum serta pakaian musim panas dan musim dingin bagi para narapidana. ${ }^{10}$ Bahkan istri Harun ar-Rasyid, Zubaidah menjadi terkenal kedermawanannya, terutama karena idenya untuk menggali sumur-sumur sepanjang lintasan haji dari Iraq sampai ke Mekkah yang tentunya sangat banyak mambantu para kafilah haji selama perjalanan mereka. ${ }^{11}$

Perhatian Harun ar-Rasyid terhadap perkembangan ilmu pengetahuan juga sangat besar. Terbukti dengan maraknya proyekproyek penerjemahan buku-buku dari berbagai bahasa ke dalam bahasa Arab. Pada masa pemerintahannya hidup tiga tokoh utama fikih Islam; Imam Malik bin Anas yang wafat pada 179 H/795 H, Imam Muhammad bin Idris as-Syafi'i yang wafat pada tahun 204 H/ $817 \mathrm{M}$ dan Imam Ahmad bin Hambal yang wafat pada tahun 780 H/ 855 M. Selain itu, pada masa kepemimpinannya muncul tokoh-tokoh yang sangat berpengaruh dalam dunia bahasa dan kesusatraan, tasawwuf serta tokoh-tokoh dalam ilmu-ilmu eksak.

${ }^{8}$ Ibid., hlm. 98.

${ }_{9}$ Ahmad Syalabi, Sejarah dan Kebudayaan Islam 3. (Jakarta: Pustaka al Husna. 1993), hlm. 108.

${ }^{10}$ Ibid., hlm. 110.

${ }^{11}$ Marshall G.S. Hodgson, The Venture of Islam: Iman dan Sejarah dalam Peradaban Islam Masa Klasik Islam. (Jakarta: Penerbit Paramadina. 2002), hlm. 80. 
Kitab al-Aghani yang sangat terkenal itu merupakan karya dalam dunia sastra yang muncul pada masa pemerintahan Harun arRasyid. Disamping itu, salah satu karya sastra yang dikenal oleh dunia hingga saat ini adalah kisah seribu satu malam. ${ }^{12}$

Perkembangan ilmu pengetahuan ini tidak hanya terlihat di Baghdad sebagai pusat pemerintahan dinasti Abbasiyah, namun juga di Kufah, Basrah, Jundeyvebar dan Harran. Tidak hanya penduduk beragama Islam yang ikut serta dalam menyemarakkan geliat pertumbuhan ilmu pengetahuan pada masa itu, para dzimmy juga mengambil peran dalam penerjemahan teks-teks filsafat dan medis helenisme klasik dari bahasaYunani ke dalam bahasa Arab.

Perhatian Harun ar-Rasyid terhadap ilmu pengetahuan juga terlihat dalam penunjukan guru bagi para putra-putranya. Sebagai seorang khalifah, Harun ar-Rasyid sadar betul bahwa dia harus mempersiapkan putra-putranya dengan bekal yang cukup agar kelak mereka bisa melanjutkan tugas khilafah ini.

\section{Konsep Pendidikan Karakter Harun ar-Rasyid}

Sadar akan pentingnya pendidikan karakter, Harun arRasyid pernah berpesan kepada Ahmar yang ditunjuknya sebagai guru bagi putra mahkotanya Abu Abdullah Muhammad Al-Amin yang kelak menggantikan posisi khalifah sepeninggal Harun arRasyid. Pesan yang ditulis oleh Harun ar-Rasyid ini mengandung konsep-konsep pendidikan karakter yang ingin ia sampaikan kepada Ahmar sang guru agar kelak dalam proses pendidikan putra mahkotanya al-Amin konsep-konsep tersebut menjadi bagian dari aturan yang harus dipenuhi oleh Ahmar. Adapun pesan tersebut adalah:

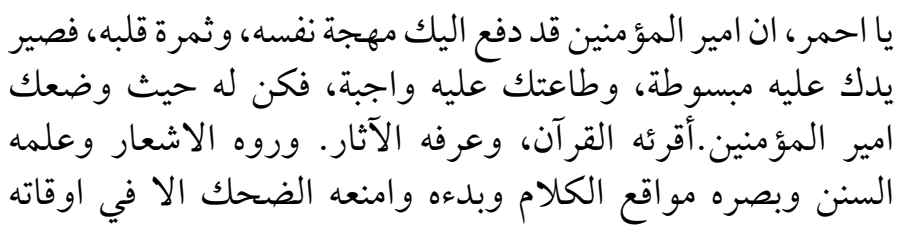

${ }^{12}$ Joesoef Sou'yb, Sejarah Daulat, hlm. 131. 


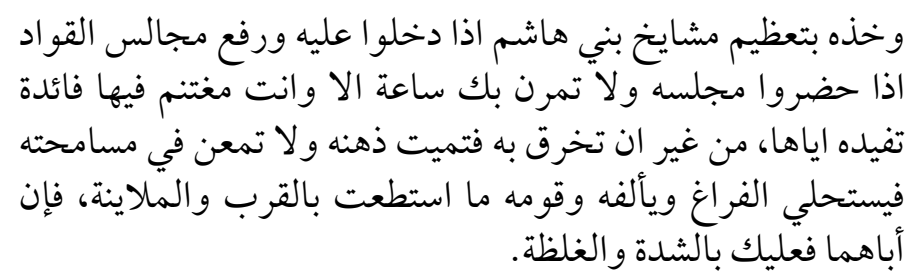

'Wahai Ahmar, saat ini Amirul mu'minin telah memasrabkan kepadamu buah hatinya (Al-Amin). Maka bukalah tanganmu untuk menyambutnya, dan dia wajib mentaatimu. Maka posisikanlah dirimu sebagaimana engkau telah dipercaya oleh Amirul mu'minin. Ajarkan padanya cara membaca alQuran, kenalkan padanya hadits Nabi Muhammad $S A W$, ajarkan padanya tentang syiir, kenalkan padanya tuntunan sunnab Rasul $S A W$, serta ajarkan padanya keterampilan retorika. Tuntunlab ia agar tidak tertawa kecuali pada saat yang tepat. Tuntunlah ia untuk menghormati keluarga besar Bani Hasyim jika mereka sedang datang ke istana, serta ajarilah ia untuk. menghormati pasukan tentara kerajaan. Janganlah engkau lengah sedikitpun dalam mendidiknya, serta jangan menggunakan kekerasan karena itu akan mematikan hati dan perasaannya. Namun di sisi lain janganlah engkau terlalu permisif sebingga dia merasa nyaman membuang-buang waktu. Jika engkau bendak meluruskannya atas suatu perkara maka lakukanlah dengan pendekatan dan lemah lembut, namun jika cara ini tidak diindabkan olehnya maka kamu berhak mengingatkannya dengan cara yang keras".

Wasiat yang ditulis oleh Harun ar-Rasyid untuk guru putra mahkotanya ini mengandung nilai-nilai pendidikan karakter yang luar biasa yang menjadi perhatian sang Amirul Mu'minin. Bahkan nilai-nilai pendidikan karakter ini tetap relevan untuk diterapkan dalam dunia pendidikan modern saat ini. Berikut ini rincian dari pendidikan karakter yang terdapat dalam wasiat Harun ar-Rasyid kepada Ahmar, guru spriritual terpilih yang dipercaya untuk menyiapkan karakter putra mahkota yang kelak akan menjadi penerus estafet khilafah Bani Abbas.

\section{a. Pentingnya Kesiapan dan Ketauladanan Seorang Guru}

Dalam wasiat yang ditulisnya kepada Ahmar, Harun ar-Rasyid menegaskan pentingnya peran guru dalam proses pendidikan. Dalam wasiat tersebut Harun ar-Rasyid meminta agar Ahmar sebagai guru harus siap menerima amanah yang dipercayakan kepadanya. Dapat dibayangkan bagaimana mungkin sebuah proses pendidikan bisa berjalan dengan baik jika guru 
sebagai salah satu unsur penting pendidikan tidak siap baik secara materi maupun secara moral. Kesiapan materi yang akan diajarkan tentu menjadi satu hal yang sangat urgen dalam proses pendidikan. Hal ini karena guru merupakan sumber ilmu yang diharapkan mampu mentransfer ilmu pengetahuan kepada para peserta didik, jika penguasaan terhadap materi ajar tidak benarbenar dipersiapkan oleh seorang guru, maka proses transfer ilmu pengetahuanpun tidak akan berjalan maksimal.

Dalam konteks pendidikan karakter, kesiapan moral seorang guru menjadi hal yang sangat diperhatikan, karena guru adalah panutan bagi para peserta didik. Rasulullah saw merupakan seorang guru teladan yang patut dicontoh oleh semua guru. Beliau selalu memberi contoh sebelum meminta seseorang untuk melakukan sesuatu. Salah satu contoh kongkrit akhlak Rasulullah terkait dengan pentingnya ketauladanan seorang guru adalah bahwa ketika beliau mengajarkan ummatnya untuk menjadi pribadi yang mudah memaafkan kesalahan orang lain dan tidak mudah mendendam. Sejarah telah mencatat bahwa Rasulullah saw adalah orang pertama yang menjenguk orang yang selama ini rajin melempari beliau dengan kotoran onta, saat beliau sedang sakit. Beliau juga dengan sabar menyuapi seorang yahudi (buta) yang setiap kali selalu mencela Rasulullah saw.

Akan sulit kiranya bagi seorang guru untuk mengajarkan tentang nilai dan akhlaq sementara dia sendiri belum bisa mengaplikasikan nilai-nilai tersebut dalam dirinya sendiri. Maka ajaran untuk memulai kebaikan dari diri sendiri merupakan konsep yang luar biasa dan mencerminkan pendidikan yang futuristik, ada beberapa karakter utama yang harus dimiliki oleh seorang pendidik, karakter tersebut adalah: ${ }^{13}$

${ }^{13}$ Agus Wibowo, Pendidikan Karakter di Perguruan Tinggi. (Yogyakarta: Pustaka Pelajar. 2013), hlm. 67. 
1) Komitmen

Komitmen bagi seorang pendidik adalah tekad yang kuat untuk melaksanakan tanggungjawabnya sebagai seorang pendidik. Komitmen ini berdampak besar terhadap ketajaman visi, rasa memiliki serta tanggung jawab atas amanah yang diembannya.

2) Kompeten

Kompeten adalah kemampuan seorang pendidik dalam melaksanakan tugas pembelajaran dan memecahkan berbagai masalah yang muncul dalam rangka mencapai tujuan pendidikan yang telah ditetapkan. Kompetensi seorang pendidik ditandai dengan keahlian di bidangnya, menjiwai profesi yang dijalani, memiliki kompetensi pedagogik, kepribadian, sosial dan profesional.

3) Kerja keras

Kerja keras merupakan kunci utama keberhasilan seseorang, termasuk juga seorang guru dalam melaksanakan tugasnya. Kerja keras seorang guru sangat diperlukan terutama dalam proses internalisasi pendidikan karakter bagi anak didiknya. Indikator yang menunjukkan bahwa seorang guru adalah sosok pekerja keras adalah selalu bekerja ikhlas dan sungguh-sungguh, bekerja melebihi target dan produktif.

4) Konsisten

Konsisten atau istiqamah adalah kemampuan untuk melakukan sesuatu dengan tekun terus-menerus secara sabar dan ulet. Karakter konsisten ini menjadi indikator bahwa seorang guru benar-benar menjiwai tugasnya sebagai seorang pendidik.

5) Sederhana

Kesederhanaan merupakan cermin keluhuran hati dalam diri seseorang. Kesederhanaan yang memancar dari keluhuran budi seseorang ini justru menjadi daya tarik 
tersendiri bagi seorang guru. Kesederhanaan bukanlah simbol kemiskinan, justru kesederhaan merupakan kekayaan yang paling berharga. Rasulullah saw merupakan contoh nyata sosok guru yang sederhana. Kedudukannya yang mulia di sisi Allah tentu bukanlah penghalang untuk meminta kekayaan yang melimpah untuk beliau dan keluarganya, namun hal itu tidak beliau lakukan, dan justru kesederhanaan itu yang menarik simpati banyak orang pada masa itu untuk ikut memenuhi panggilan tauhid.

6) Kemampuan Berinteraksi

Kemampuan berinteraksi merupakan modal utama bagi seorang guru dalam proses pembelajaran. Interaksi ini tidak hanya penting dalam proses transfer ilmu pengetahuan, namun juga merupakan modal untuk menjalin ikatan emosiaonal dengan peserta didiknya, sehingga tujuan pembelajaran dapat tercapai dengan baik.

7) Melayani Secara Maksimal

Dalam sebuah hadits yang diriwayatkan oleh Anas bin Malik RA, disebutkan bahwa Rasulullah saw bersabda:

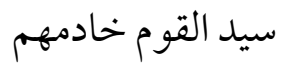

"Pemuka suatu kaum pada bakeekatnya adalah pelayan bagi kaumnya"

Hadits di atas mengajarkan nilai pengabdian yang luar biasa yang harus disadari betul oleh para pemimpin. Karena sesungguhnya amanah yang dibebankan kepada mereka memberi konsekwensi pengabdian yang tidak ringan. Dalam konteks pendidikan, seorang guru sejatinya merupakan pelayan bagi para peserta didiknya, dengan demikian, tugas mulia yang menjadi tanggung jawab seorang guru harus dilaksanakan secara maksimal sebagai bentuk pengabdian kepada para peserta didiknya. 
8) Cerdas

Kecerdasan mencerminkan keluasan dan pemahaman atas ilmu yang dimiliki seseorang secara komprehensif. Kecerdasan bagi seorang guru merupakan kunci keberhasilannya dalam proses pembelajaran. Jika salah satu syarat yang harus dimiliki oleh seorang murid menurut Imam Syafi'I RA adalah kecerdasan atau dzakaa, maka selayaknya prasyarat ini harus dimiliki oleh seorang guru.

\section{b. Taat Kepada Guru}

Strata sosial yang tinggi, serta kemewahan hidup di istana tidak menutup mata hati Sang Khalifah Harun ar Rasyid. Dia tetap mengajarkan kerendahan hati kepada Al-Amin yang kelak akan meneruskan estafet kekhilafahan Bani Abbas. Hal ini terbukti dalam perintah yang tertuang dalam wasiat yang ia tulis untuk AlAhmar. Dalam wasiat tersebut jelas tertulis وطاعتك عليه واجبة yang menyuratkan kewajiban Al-Amin untuk mentaati Al-Ahmar sebagai gurunya. Penanaman karakter rendah hati atau tawadlu' menjadi sesuatu yang menarik perhatian Harun ar Rasyid, hal ini muncul dari kesadaran akan ancaman yang timbul dari sifat takabbur dalam diri seorang pemimpin. Jika seorang pemimpin sekelas Al-Amin mempunyai sifat takabbur, maka sudah dapat dibayangkan gaya kepemimpinannya kelak. Dia akan menjadi pemimpin yang otoriter dan semena-mena.

Kerendahan hati seperti ini, menjadi sesuatu yang sangat susah dimiliki oleh seseorang tanpa penanaman dan pelatihan sejak dini. Perintah Harun ar-Rasyid kepada Al-Amin untuk mentaati AlAhmar merefleksikan kesadaran akan pentingnya penanaman sifat tawadlu' dalam diri sang putra mahkota. Sayyidina Ali r.a pernah berkata bahwa beliau siap mengabdi pada seseorang yang telah mengajarinya meski hanya satu huruf. Sungguh ungkapan ini sarat makna dan mencerminkan keluasan dan kerendahan hati yang muncul dalam diri seorang khalifah sekelas Ali r.a. 
Dalam konteks pendidikan karakter di Indonesia, penanaman karakter rendah hati menjadi tugas besar bagi para orang tua, guru dan seluruh masyarakat secara umum. Berita tentang maraknya kekerasan yang melibatkan siswa-siswi dalam dunia pendidikan kita seolah menjadi santapan rutin yang harus kita terima. Jika ditelisik, kekerasan, tawuran dan kekacauan yang banyak muncul di Negara ini bersumber pada tidak adanya rasa menghormati, menghargai dan menerima perbedaan. Dan kesemuanya muncul karena tidak adanya karakter tawadlu' atau kerendahan hati.

\section{Mengajarkan Quran dan Sunnah}

al-Quran dan Sunnah ibarat undang-undang yang telah ditetapkan oleh Allah bagi ummat Islam tanpa mengenal batasan waktu dan tempat. Karakter dari keduanya yang universal, menjadikan al-Quran dan Sunnah sangat sesuai dengan kebutuhan ummat manusia lintas tempat dan waktu. Jika demikian, Indonesia meskipun bukan Negara Islam, tetapi merupakan Negara dengan jumlah penduduk Muslim terbesar di dunia, maka seharusnya merupakan Negara ideal sebagaimana dijanjikan al-Quran dan Sunnah. Hal itu jika ummat Islam di negeri ini benar-benar mengikuti ajaran yang tertuang dalam al-Quran dan Sunnah secara kaffah. Namun amat disayangkan, kenyataan berkata lain. Ajaran Islam justru lebih mudah ditemukan di Negara-negara berlabel Non-Muslim. Contoh sederhana saja, betapa rendahnya kesadaran penduduk negeri ini terhadap pentingnya menjaga kebersihan. Padahal sejak kecil anak-anak sudah dilatih untuk menghafal hadits tentang pentingnya kebersihan. Namun hafalan tinggallah hafalan, tidak ada bukti empirik yang merefleksikan pemahaman atas hadits tersebut dalam kehidupan nyata. Masih banyak penduduk di negeri ini yang dengan ringan tangan membuang sampah sembarangan, tidak peduli dengan dampak global yang muncul dari kebisaan buruk tersebut. Dan hal ini tidak hanya dilakukan oleh satu atau dua orang saja, namun dilakukan secara berjamaah oleh sebagian besar penduduk negeri ini. 
Bandingkan dengan penduduk di negara-negara yang mungkin tidak pernah mengaji apalagi mengkaji ajaran al-Quran dan Sunnah. Kesadaran mereka akan pentingnya menjaga keseimbangan alam benar-benar dibuktikan dengan menjaga kebersihan. Lalu dimana letak permasalahannya? Hal ini tentu perlu kita pelajari lebih dalam untuk memukan formula yang tepat agar ajaran-ajaran yang termaktub dalam al-Quran dan Sunnah menjadi sesuatu yang hidup dalam jiwa dan perilaku setiap penduduk di negeri ini.

Memahami al-Quran dan Sunnah menjadi suatu kewajiban bagi setiap Muslim. Melalui wasiat yang ditulisnya, Harun ar-Rasyid meminta Al-Ahmar agar mengajarkan al-Quran dan Sunnah kepada Al-Amin. Tidak hanya mengajarinya tata cara membaca al-Quran dan Sunnah, namun juga menanamkan nila-nilai yang terkandung di dalamnya. Pendidikan karakter yang tersurat dari pengajaran alQuran dan Sunnah adalah pembentukan pribadi yang taat kepada Allah dan rasul-Nya serta menjadikan ajaran agama sebagai way of life. Jika demikian, tentu Harun ar-Rasyid tidak perlu was-was untuk menyerahkan tampuk kekhilafahan pada putra mahkotanya AlAmin.

\section{Mengajarkan Seni}

Perhatian Harun ar-Rasyid terhadap ilmu pengetahuan dan seni dibuktikan dengan dukungnnya terhadap para ulama' dan seniman pada masa itu. Kisah tentang 1001 malam yang banyak dinisbahkan pada sosok Harun ar-Rasyid juga bukti nyata kecintannya pada dunia seni. Terlepas dari kontroversi terkait hukum seni dalam arti sempit, sebenarnya ayat-ayat al-Quran mengajarkan nilai-nilai seni. Dari segi pemilihan huruf, akhiran yang sama dari setiap ayat dalam satu topik pembahasan tertentu juga termasuk dalam bagian ilmu seni.

Seni juga terbukti mampu menjadi alat terapi berbagai penyakit, terutama penyakit-penyakit yang berhubungan dengan kesehatan kejiwaan dan rohani. Pada masa awal penyebaran Islam, kaum Muslimin diingatkan dengan kisah masuknya Umar 
al-Faruq dalam agama Islam karena tertarik dengan indahnya bacaan al-Quran yang dilantunkan oleh adiknya. Pada era moden ini, banyak ilmuwan yang mengklaim dalam penelitian mereka bahwa ternyata musik dapat mempengaruhi kejiwaan seseoarang, bahkan saat ia masih di dalam kandungan ibunya. Sehingga sering direkomendasikan agar para ibu hamil memperdengarkan lagulagu tertentu pada janin dalam kandungan mereka. Tentu akan lebih besar dampak positif yang muncul jika yang dilantunkan adalah ayat-ayat al-Quran yang kedudukannya jauh lebih tinggi dari sekedar syair-syair buatan manusia.

Pengajaran seni bagi Harun ar-Rasyid merupakan sarana untuk membangun karakter al-Amin. Meski tidak secara langsung mengajarkan nilai-nilai tertentu, namun dampak psikologis yang muncul dari pengajaran seni diharapkan mampu membangun karakter dan kepribadian yang lemah lembut dalam diri sang putra mahkota.

\section{Mengajarkan Retorika}

Dalam Kamus Besar Bahasa Indonesia disebutkan bahwa salah satu definisi retorika adalah keterampilan berbahasa secara efektif. Keterampilan berbahasa tentu harus dimiliki oleh semua orang agar dapat berkomunikasi secara efektif dalam rangka mencapai tujuan yang diinginkan. Apalagi bagi seorang khalifah, retorika merupakan keterampilan yang wajib dikuasai, karena kepiawaian dalam berdiplomasi sangat menentukan keberlangsungan suatu rezim atau pemerintahan dalam percaturan global.

Selain sebagai sebuah bakat yang tidak dimiliki oleh semua orang, retorika sebagai sebuah keterampilan sejatinya bisa diajarkan dan ditekuni oleh seseorang. Karenanya melalui wasiatnya ini, Harun ar-Rasyid menginginkan agar al-Amin kelak tumbuh menjadi seorang yang mempunyai keterampilan retorika yang berkarakter. Karena kemampuan retorika secara tidak langsung akan membawa seseorang pada kemampuan untuk 
menempatkan diri di setiap kondisi yang ada di hadapannya. Rasulullah saw pun pernah berpesan kepada ummatnya agar mampu memilah dan memilih setiap kata yang akan kita ucapkan dengan memperhatikan lawan bicara atau atau audien yang ada di hadapan kita. Pesan tersebut beliau sampaikan dalam sebuah hadits marfu' yang diriwayatkan oleh Ad-Dailamy dari Ibnu Abbas yang berbunyi:

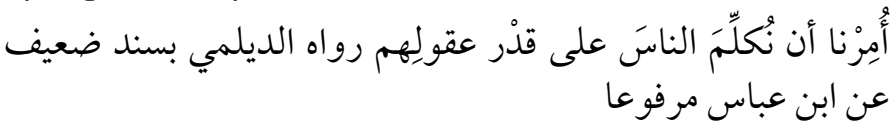

"Kami diperintabkan untuke berbicara dengan orang lain sesuai dengan kondisi dan kecerdasannya".

Hadits ini mengandung ajaran tentang etika komunikasi yang sangat luhur. Harga diri seseorang seringkali tergadaikan dengan sikap dan keterampilannya dalam berkomunikasi. Sungguh sangat disayangkan jika seorang khalifah dicemooh oleh rakyatnya karena kesalahannya dalam bertutur, karena pada saat itu harga dirinya sudah tercoreng di hadapan mereka. Karakter yang ingin dibangun dari pengajaran retorika ini diantaranya adalah kematangan emosional dalam menghadapi lawan bicara dalam berbagai kondisi.

\section{Tidak Banyak Tertawa}

Dalam sebuah hadits sahih yang diriwayatkan oleh Abu Hurairah RA disebutkan bahwa Rasulullah saw bersabda:

$$
\text { لا تكثرو الضحك فإن كثرة الضحك تميت القلب رو اه أبو هريرة }
$$

Di tengah gemerlap dan euphoria dunia modern saat ini, nasihat Rasulullah saw terasa amat menyejukkan dan menyentuh dimensi kesadaran kita untuk kembali berbenah menyempurnakan keindahan akhlak yang diajarkan beliau. Tentu saja hadits di atas tidak melarang siapapun untuk tertawa, karena tertawa secara medis juga terbukti membantu seseorang mempunyai harapan hidup lebih lama atau panjang umur, karena tertawa juga 
merefleksikan kelapangan hati dalam menghadapi berbagai kondisi hidup. Namun yang perlu digaris bawahi adalah bahwa tertawa jika dilakukan terus-menerus dan berlebihan dikhawatirkan membuat seseorang lupa dengan tujuan hidup yang sesungguhnya, yaitu mempersiapkan bekal untuk kehidupan akhirat.

Banyak tertawa juga menyebabkan seseorang kehilangan sense kepekaan dalam menyikapi keadaan. Padahal kepekaan merupakan prasyarat yang harus dimiliki oleh seorang pemimpin agar ia bisa melihat berbagai permasalahan yang terjadi dari berbagai sudut pandang, sehingga keputusan yang dibuat untuk menyelesaikan masalah tersebut dapat diterima oleh semua pihak. Hal ini yang mendorong Harun ar-Rasyid memberi pesan khusus agar al-Ahmar selalu memperingatkan muridnya al-Amin untuk tidak banyak tertawa.

\section{Menghormati Keluarga Besar}

Di tengah derasnya arus globalisasi dan perkembangan teknologi informasi modern, menyambung hubungan kekeluargaan atau silaturrabim tidak lagi dimaknai dengan pertemuan fisik. Berhubungan melalui alat telekomunikasi modern sudah dianggap mewakili kebersamaan antar anggota keluarga.

Dengan dalih kesibukan dan jarak yang memisahkan, kemajuan teknologi memang memberi jalan keluar bagi anggota keluarga yang saling terpisah untuk tetap menyambung silaturrahim di antara mereka, namun di sisi lain tentu saja bertemu secara langsung membawa dampak yang lebih besar, baik pada hubungan psikologis antar anggota keluarga maupun dampak sosial yang lainnya. Kehangatan dan kekuatan tali persaudaraan akan lebih terasa, tidak hanya pada satu generasi, namun juga pada generasi-generasi penerus keluarga yang tentunya semakin lama semakin berkembang.

Di era modern ini tidak jarang kita temukan seorang anak yang tidak lagi mengenali saudara-saudara inti dari kedua orang tuanya. Bahkan mereka tidak tahu siapa saja yang termasuk dalam 
kategori mahram dan bisa menjadi wali bagi mereka. Sungguh sangat disayangkan, apalagi dalam Islam urusan nasab mendapat perhatian yang sangat serius, karena hal ini berhubungan dengan berbagai permasalahan serius terkait hak waris, hubungan mahram, hak wali dan sebagainya.

Dalam konteks kehidupan yang lebih luas, silaturrahim mempunyai peran yang sangat besar dalam proses aktualisasi diri dan juga pengembangan potensi diri. Konsep networking yang banyak dikenal dalam dunia bisnis sejatinya merupakan adopsi dari ajaran silaturrahim yang dikenalkan Islam sejak awal risalah. Jika konsep networking ini begitu penting, maka tidak berlebihan jika kemudian Allah pernah mengingatkan ummat manusia untuk tetap menjaga hubungan baik dalam keluarga, bahkan Rasulullah saw dalam sebuah hadits melaskan bahwa Allah akan memberi balasan bagi orang yang memutuskan hubungan silaturahmi sebelum ia memejamkan mata untuk meninggalkan dunia.

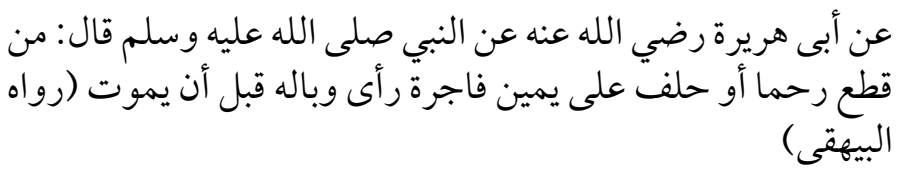

'Dari Abu Hurairah, dari Nabi SAW bersabda: Barang siapa memutuskan tali silaturabim atau bersumpah dengan sumpah dusta, maka dia akan melihat akibat dari perbuatannya itu berupa malapetaka sebelum kedatangan kematiannya." (H. R. Baihaqi)

Di sini bisa kita lihat sebegitu besar makna dari ajaran silaturahmi tersebut, hingga Allah membalas orang yang memutuskan tali persaudaraan tidak hanya berupa siksa di akhirat namun juga siksa di dunia dalam bentuk yang beragam.

Konsep silaturahmi ini begitu difahami oleh Harun arRasyid, sehingga ia merasa perlu untuk menyampaikan secara khusus kepada Al-Ahmar agar mengajarkan kepada putra mahkotanya Al-Amin akan pentingnya silaturahmi, meski yang disebut secara eksplisit dalam wasiatnya adalah Bani Hasyim yang merupakan keluarga besarnya. 
Dalam konteks pendidikan karakter di Indonesia, perlu kiranya ditekankan kembali pentingnya hubungan persaudaraan tidak hanya dalam konteks keluarga, namun juga dalam konteks sesama warga Negara dengan berbagai latar belakang sosial, budaya, agama, dan pendidikan agar tercipta masyarakat yang saling menjaga dan menghargai untuk kemudian bersatu bersama-sama membangun Negara ini menjadi lebih baik di masa yang akan datang sebagaimana diamanatkan oleh Pancasila dan Undang-Undang Dasar 1945. Dengan begitu, ancaman disintegrasi bangsa yang saat ini menjadi kekhawatirkan sebagian kalangan, dengan sendirinya akan teratasi karena proses integrasi terjadi secara terus menerus dan berkesinambungan antarsesama anak bangsa dari generasi ke generasi.

\section{Mampu Menempatkan diri}

Sadar akan pentingnya kemampuan untuk menempatkan diri dalam berbagai kondisi, Harun ar-Rasyid meminta kepada Ahmar agar berkenan mengajarkan sang putra mahkota etika ini. Seorang pemimpin yang mampu menempatkan diri di tengah masyarakat yang dipimpinnya tentu akan dengan mudah membangun komunikasi yang yang efektif di antara mereka. Komunikasi yang terbangun merupakan kunci utama penyelesaian berbagai masalah yang terjadi di tengah masyarakat.

Dalam konteks ke-Indonesiaan, Pemimpin dengan kemampuan membangun komunikasi yang harmonis menjadi sosok yang benar-benar dirindukan di negeri ini. Berbagai masalah yang tak kunjung usai menimpa negeri ini seakan menunggu tangan ajaib yang mampu menyelesaikannya dengan menyentuh akar utama permasalahan yang sebenarnya terjadi dan mendahulukan kepentingan masyarakat di atas kepentingan pribadi atau golongan termasuk partai politik pengusungnya.

Masih lekat di benak kita dan terus menjadi fokus pemberitaan di berbagai media massa bagaimana masyarakat menyambut dengan hangat kedatangan sosok pemimpin yang 
"berbeda" dan memiliki gaya kepemimpinan membumi dan merakyat. Kemampuan untuk menarik simpati masyarakat dengan gaya kepemimpinan yang sangat sederhana muncul dari kemampuan untuk menempatkan diri. Tidak hanya masyarakat yang terpikat dengan gaya kepemimpinan model ini, namun dunia global juga angkat topi terhadap gaya kepemimpinannya yang bersahaja. Kesederhanaan yang melekat dalam diri seorang pemimpin tidak lantas menjadikannya direndahkan, bahkan justru kesederhanaan itu yang mempunyai daya tarik yang luar biasa.

Rasulullah saw sebagai tauladan yang sempurna telah mengajarkan kepada ummatnya bagaimana seharusnya seorang pemimpin bersikap dan menempatkan diri baik di tengah masyarakat maupun di tengah para pemimpin negara-negara tetangga. Bahkan jauh sebelum Muhammad SAW diangkat menjadi Nabi, beliau mampu menjadi penengah dalam menyelesaikan konflik yang terjadi di tengah masyarakat Arab pada masa itu hingga kemudian Muhammad yang masih remaja saat itu mendapat gelar kehormatan al-Amin.

Setelah kenabian dan keputusan berhijrah dari Makkah ke Madinah, Muhammad SAW menuliskan tinta emas keberhasilannya membangun Negara Madinah yang sampai saat ini menjadi profil Negara impian setiap individu. Kemampuan Nabi Muhammad SAW sebagai seorang pemimpin Negara dalam menyelesaikan berbagai permasalahan yang ada tidak lepas dari kepiawaian beliau dalam menempatkan diri di tengah masyarakat.

\section{Menghargai waktu}

Setiap orang mempunyai jatah waktu yang sama dalam sehari semalam, namun mengapa ada sebagian dari mereka yang selalu merasa kekurangan waktu dan ada pula yang dengan tenang menghabiskan waktu dengan sia-sia. Ada sebagian yang mempu mencapai prestasi yang luar biasa dan sebagian yang lain tidak mengukir satu prestasi apapun dengan jatah waktu yang sama. 
Ternyata yang membedakan di antara kedua golongan di atas adalah time management atau keterampilan mengatur waktu dan menggunakannya dengan efektif dan efisien.

Menghargai waktu tentu tidak lepas dari kemampuan untuk menentukan skala prioritas dari sekian banyak tugas yang diterima oleh seseorang. Di samping itu kejelian untuk menangkap setiap peluang kemajuan juga berperan dalam proses time management ini. Mereka yang berhasil dan mampu mencatat berbagai prestasi dapat dipastikan adalah pribadi dengan kemampuan time management yang bagus.

Islam sejatinya telah mengajarkan keterampilan time management ini dengan begitu detil. Jika diamati dengan jeli, kewajiban shalat lima waktu dalam sehari semalam sejatinya merupakan mesin pengatur waktu yang sangat cermat dan akurat. Dengan kewajiban shalat lima waktu dalam sehari semalam setiap muslim diharapkan mampu menghargai waktu dan menggunakannya dengan sebaik mungkin. Kewajiban shalat subuh di setiap pagi mengajarkan kedisiplinan untuk memulai aktifitas sepagi mungkin agar tugas yang menumpuk dapat segera terselesaikan. Shalat dzuhur di tengah hari mengingatkan manusia untuk tidak lalai menjaga keseimbangan antara tuntutan pekerjaan dengan hak ragawi untuk sejenak beristirahat. Shalat ashar mengajarkan manusia untuk terus konsisten atau istiqamah dalam menjalankan setiap aktifitas. Shalat maghrib dengan jatah waktu yang terbatas mengajarkan manusia untuk dapat memanfaatkan waktu sebaik mungkin dan shalat isya' yang merupakan shalat terakhir di setiap hari seakan menjadi pengingat manusia agar selalu menutup setiap aktifitas dengan penuh optimisme untuk menghadapi hari esok yang lebih baik.

Tidak berlebihan kiranya jika kemudian shalat ditetapkan sebagai tolak ukur keimanan seseorang karena shalat memang mengajarkan kedisiplinan tingkat tinggi. Maka bisa dijamin bahwa siapapun yang selalu mengerjakan shalat tepat waktu dia adalah seseoarang yang mempunyai tingkat kedisiplinan 
yang tinggi dengan kemampuan time management yang bagus, namun sebaliknya mereka yang terbiasa mengakhirkan shalat atau bahkan meninggalkannya pasti merupakan pribadi dengan tingkat kedisiplinan yang rendah dan kwalitas time menegement yang rendah pula.

Sedemikian penting kedudukan time management ini sehingga seringkali dikaitkan dengan keberhasilan dan kegagalan seseorang. Maka tidak heran jika kemudia Harun ar-Rasyid meminta kepada al-Ahmar untuk mengajarkan kepada al-Amin bagaimana menghargai waktu dan memanfaatkannya dengan baik agar kelak saat sang putra mahkota memimpin daulah abbasiyyah dapat mencatat prestasi yang luar biasa.

\section{Mendidik Tanpa Kekerasan}

Mendidik sebagai poses yang melibatkan dua pihak tentu tidak lepas dari keterlibatan emosi, baik emosi dari pihak guru sebagai pendidik ataupun murid sebagai peserta didik. Dalam wasiat sebelumnya, Harun ar-Rasyid meminta al-Amin untuk mentaati al-Ahmar sang guru sebagai bentuk perhatian Harun ar-Rasyid akan pentingnya menjaga emosi al-Amin dalam kedudkannya sebagai seorang murid. Di sisi lain Harun ar-Rasyid juga meminta kepada al-Ahmar untuk menggunakan pendekatan nir kekerasan (nonviolent approacb) saat mendidik dan membimbing al-Amin. Wasiat ini menandakan bahwa Harun ar-Rasyid meminta agar al-Ahmar benar-benar bisa menjaga emosinya saat mendidik al-Amin. Dengan demikian, dalam wasiat ini keseimbangan emosi dari kedua belah pihak yang terlibat dalam proses pendidikan ini benar-benar diperhatikan oleh Harun ar-Rasyid, sehingga diharapkan tercipta hubungan yang harmonis antara guru dan murid dengan prinsip saling menghargai.

Dalam konteks pendidikan di Indonesia, kekerasan dalam dunia pendidikan masih kerap terjadi, baik kekerasan yang terjadi antar siswa dalam bentuk tawuran maupun kekerasan yang dilakukan oleh guru terhadap muridnya. Bahkan kekerasan 
juga terjadi di level perguruan tinggi dalam berbagai bentuknya. Terkait dengan krisis mentalitas dan moral peserta didik, ada beberapa hal yang menjadi akar masalah dari krisis ini dalam dunia pendidikan nasional. ${ }^{14}$ Pertama, arah pendidikan telah kehilangan obyektifitasnya. Di sini, sekolah tidak lagi melaksanakan fungsinya sebagai tempat untuk membangun dan membentuk karakter peserta didik. Ada hubungan yang terputus antara guru sebagai representasi dari sekolah dengan murid sebagai peserta didik. Seorang guru tidak lagi punya kemauan untuk menegur muridnya yang melakukan kesalahan. Kondisi ini banyak ditemukan di kota besar, dimana seringkali seorang guru merasa tidak punya kewenangan untuk menegur kesalahan seorang murid hanya karena perbedaan status sosial yang ada.

Kedua, proses pendewasaan diri tidak berlangsung baik di sekolah. Hal ini karena sekolah tidak lagi menjalankan fungsinya sebagai wadah untuk bersosialisasi bagi seluruh civitas akademika yang ada di dalamnya. Selain berfungsi sebagai lembaga yang mengembangkan kemampuan kognisi afeksi dan psikomotorik siswa, sekolah sebenarnya bertugas untuk mempersiapkan para siswa menjadi pribadi yang siap menghadapi dunia nyata yang kelak akan dihadapi oleh para siswa. Kemampuan beradaptasi, menyelesaikan masalah, bertanggung jawab dan kemandirian seharusnya merupakan nilai-nilai yang harus ditanamkan dalam diri para siswa hingga mereka mampu menjadi pribadi yang dewasa dan siap menghadapi dunia nyata di luar sekolah.

Ketiga, proses pendidikan di sekolah sangat membelenggu para peserta didik dan juga para guru. Formalisme yang dibangun dalam dunia pendidikan, proses belajar mengajar yang berjalan kaku serta beban kurikulum yang cukup berat tidak lagi menyisakan ruang bagi perkembangan imajinasi dan kreatifitas kognisi, afeksi dan psikomotorik para peseta didik. Jika ini yang

${ }^{14}$ Azyumardi Azra, Paradigma Baru Pendidikan Nasional Rekonstruksi dan Demokrasi. (Jakarta: Penerbit Buku Kompas, 2006), hlm. 179-180. 
terjadi, maka interaksi yang dibangun di lingkungan sekolah bisa dikatakan sebagai interaksi robotic. Akibatnya akan lahir anak robotic yang melakukan tindakan tanpa didasari hati nurani.

Keempat, beban kurikulum yang lebih menitikberatkan pada dimensi kognitif dan kurang memberi perhatian pada dimensi afeksi dan psikomotorik, padahal keduanya berperan penting dalam pembentukan moral, etika dan karakter yang baik. Kelima, model penyampaian materi dalam bentuk verbalisme dan menekankan pada kemampuan hafalan atau rote-memorizing menjadikan materi yang diajarkan di sekolah menjadi sesuatu yang hanya difahami oleh akal, bukan untuk diaplikasikan dalam kehidupan nyata.

Keenam, seringkali para peserta didik dihadapkan pada kondisi yang kontradiktif. Di saat para peserta didik diajarkan untuk menjadi pribadi yang jujur, disiplin, bertanggung jawab dan amanah, di saat yang sama pula mereka mendapatkan kenyataan berkata sebaliknya. Ketujuh, saat ini sangat sulit menemukan profil pribadi teladan yang bisa dijadikan contoh oleh para peserta didik, baik di lingkungan sekolahnya ataupun di tempat tinggalnya.

Sudah saatnya para pendidik untuk kembali mencontoh model pendidikan yang diberikan oleh Rasulullah saw. Pendidikan yang mengedepankan nilai-nilai humanis tanpa menggunakan kekerasan (violence). Karena terbukti bahwa model pendidikan yang beliau contohkan telah berhasil melahirkan soso-sosok agung para sahabat dengan prestasi yang gemilang tidak hanya prestasi ukrawi namun juga prestasi duniawi.

\section{Simpulan}

Dari sekian banyak wasiat yang dituliskan oleh Harun ar-Rasyid untuk al-Ahmar, kesemuanya selaras dengan konsep pendidikan karakter yang diusung oleh para pakar pendidikan modern saat ini. Hal ini menunjukkan bahwa konsep pemikiran pendidikan karakter yang diusung oleh Harun ar-rasyid mengandung nila-nilai universal yang tidak mengenal batasan 
ruang dan waktu. Bahkan beberapa konsep pendidikan karakter memunculkan sisi keunikan yang tidak ditemukan dalam konsep pendidikan karakter yang tidak terdapat dalam konsep pendidikan modern seperti wasiat Ar-Rasyid pada al-Ahmar untuk mengajarkan al-Amin agar tidak banyak tertawa. Jika tidak ditelisik dengan jeli, wasiat ini seakan-akan tidak mengandung pesan pendidikan karakter, padahal sesungguhnya pesan yang sederhana ini justru mempunyai nilai yang sangat tinggi dalam proses pendidikan karakter seseorang sebagaimana telah dijelaskan di atas.

Hal ini tentu tidak terlepas dari sosok Harun ar-Rasyid yang dikenal sebagai pribadi dengan cara pandang futuristik tanpa melupakan ajaran agama dalam setiap pesan yang dia sampaikan. Tidak berlebihan kiranya jika disampaikan bahwa kita perlu belajar lebih banyak pada tokoh-tokoh muslim dalam berbagai dimensi ilmu dan tidak mudah terpesona dengan tokoh-tokoh dari dunia barat, karena bagaimanapun karakter keagamaan yang melekat pada para tokoh muslim sudah memberikan nilai lebih dalam setiap konsep yang ditawarkan. 


\section{DAFTAR PUSTAKA}

Amstrong, Amstrong, Islam SejarabSingkat, Yogyakarta: Jendela. 2002

Azra, Azyumardi, Paradigma Baru Pendidikan Nasional Rekonstruksi dan Demokrasi, Jakarta: Penerbit Buku Kompas, 2006

Hamid, Hamdani dan Beni Ahmad Saebani. Pendidikan Karakter Perspektif Islam. Bandung: Pustaka Setia. 2013

Hodgson, Marshall G.S. The Venture of Islam: Iman dan Sejarah dalam Peradaban Islam Masa Klasik Islam. Jakarta: Paramadina. 2002

Khan, D. Yahya. Pendidikan Karakter Berbasis Potensi Diri. Yogyakarta: Pelangi Publishing. 2010

Sou'yb, Joesoef. Sejarah Daulat Abbasiyah I Jakarta: Bulan Bintang. 1997

Syalabi, Ahmad. Sejarah dan Kebudayaan Islam 3. Jakarta: Pustaka Al Husna. 1993

Syukur NC, Fatah. SejarabPeradaban Islam. Semarang: Pustaka Rizki Putra, 2009

Wibowo, Agus. Pendidikan Karakter di Perguruan Tinggi. Yogyakarta: Pustaka Pelajar. 2013 